\title{
Platformization of COVID and the Rise of Biosocial Surveillance
}

Handan Vicdan

Emlyon Business School

Follow this and additional works at: https://digitalcommons.uri.edu/mgdr

Part of the Anthropology Commons, Economics Commons, Marketing Commons, Other Business Commons, and the Sociology Commons

\section{Recommended Citation}

Vicdan, Handan (2020) "Platformization of COVID and the Rise of Biosocial Surveillance," Markets, Globalization \& Development Review: Vol. 5: No. 3, Article 2.

DOI: 10.23860/MGDR-2020-05-03-02

Available at: https://digitalcommons.uri.edu/mgdr/vol5/iss3/2

This Dialogue is brought to you for free and open access by DigitalCommons@URI. It has been accepted for inclusion in Markets, Globalization \& Development Review by an authorized editor of DigitalCommons@URI. For more information, please contact digitalcommons-group@uri.edu. 


\section{Markets, Globalization \& Development Review}
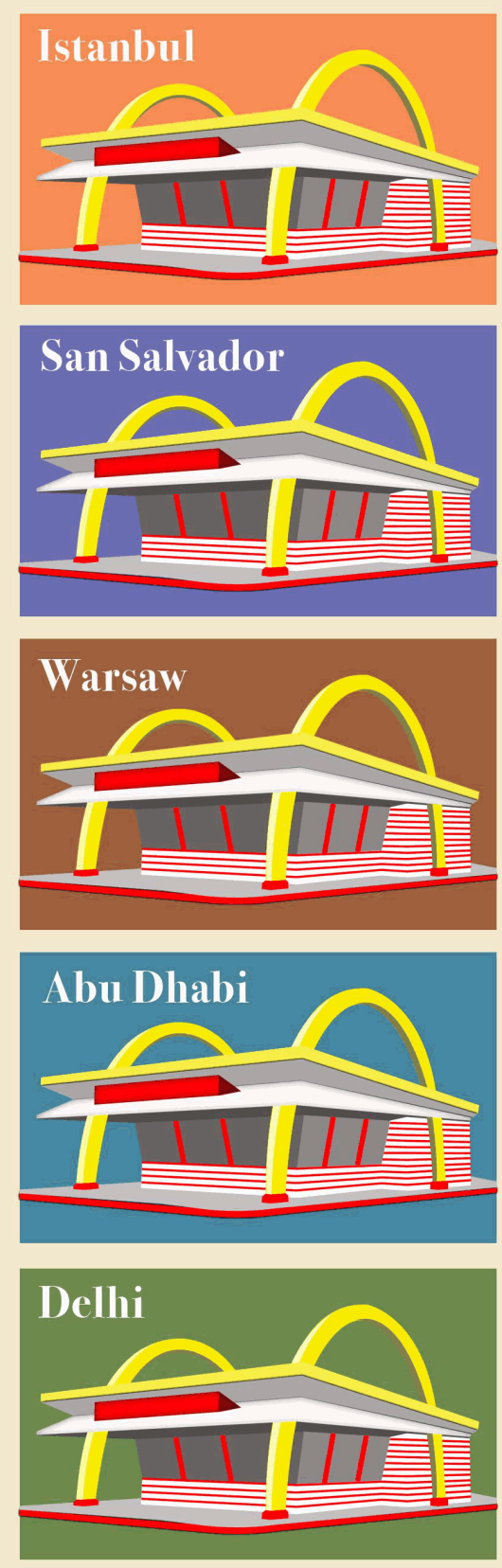
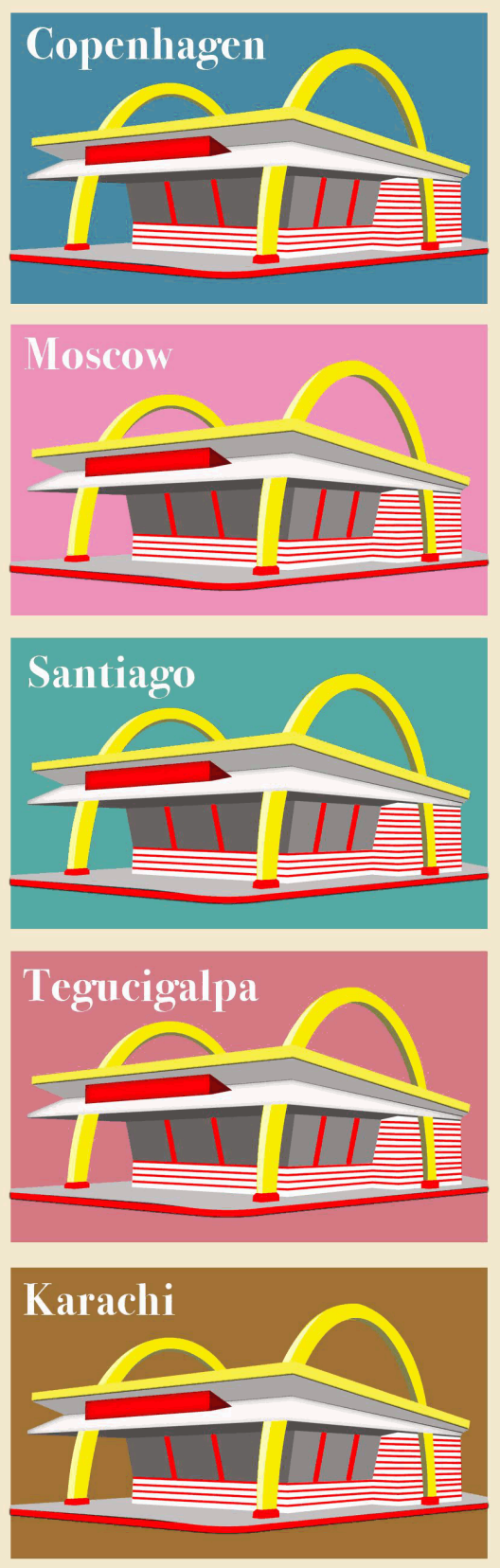
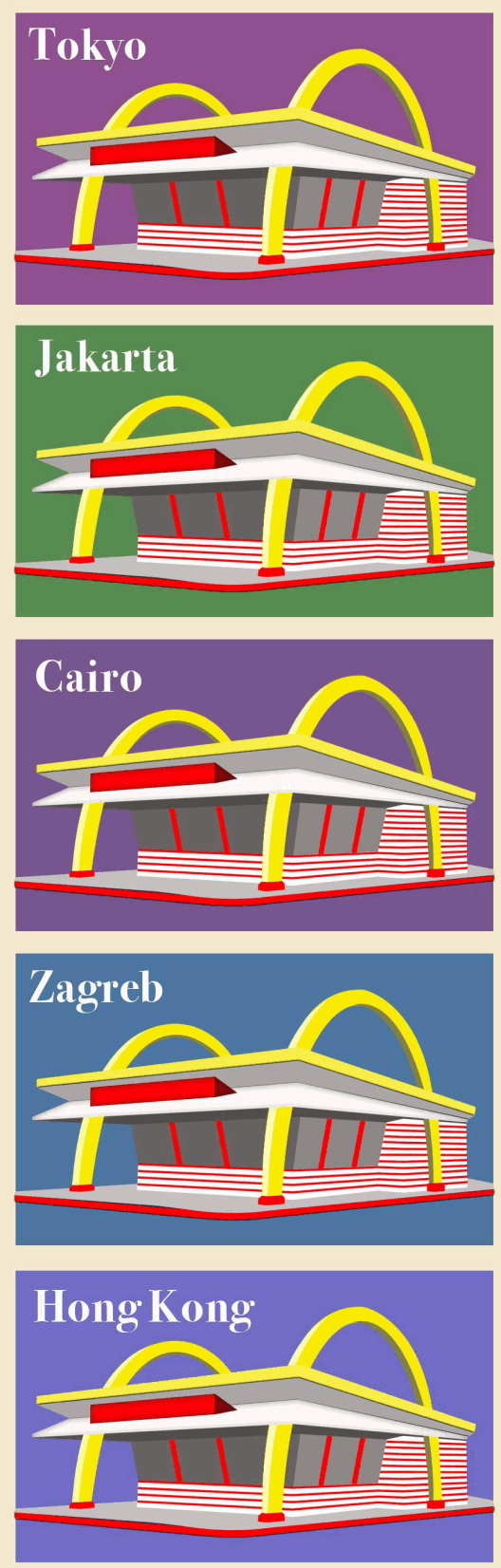

This dialogue is available in Markets, Globalization \& Development Review: https://digitalcommons.uri.edu/mgdr/ vol5/iss $3 / 2$ 


\section{Platformization of COVID and the Rise of Biosocial Surveillance}

\section{Introduction}

Platformization has emerged as a dominant infrastructural and economic model of the social web (Helmond 2015, Ozgun 2018) bringing various market actors together and enabling interactions among these actors, shaping the web's participatory nature (Gillespie 2010) and sociality (Van Dijck 2013) in unprecedented ways and paving ways for citizen empowerment and democratization (Beer 2009). Platform organizations rely on data provided by users to extract value and make profit via the datafication of our everyday life. In healthcare, platform organizations bring together diverse market actors for partnership for the creation and distribution of aggregate patient data, on which the market can act and deliver outcomes that are potentially beneficial for the parties involved. In addition, we observe the boundary of scientific expert versus layperson becoming increasingly blurred through the emergence of participatory medicine and citizen science movement enabled by new technologies and digital platforms. Patient generated medical research and knowledge enabled by these platforms lead to a new and democratized knowledge production within the medical sciences (Gibbons and Novas 2008). Patients engage in self and collective quantification and tracking of health data. Healthcare stakeholders such as governments, pharmaceuticals and research institutions can gain access to patient generated data for drug discovery and development, confirmation of randomized clinical trials, and recruitment of patients from these communities via these platforms.

In order to articulate how such platformization of patient/citizenled medical research and disease control is organized and sustained, I turn to the Foucauldian notion of biopower and Rabinow's concept of biosociality to then draw attention to what I call biosocial surveillance, which is becoming increasingly relevant in today's risk society. Indeed, global exacerbation of the Covid-19 pandemic pushes us to rethink the conventional slow-moving medical discovery and surveillance processes driven by dominant macro-institutions; indeed, the patientcitizen is increasingly becoming an active partner of the surveillance of this pandemic together with macro institutions. Biosocial surveillance is an outcome of the desire to assemble technologies and surveillance practices in order to increase the degree of surveillance capacity (Haggerty and Ericson 2000) through platforms for a more (hopefully) democratized and accessible patient care and citizen-led medical research. State enforced coronavirus quarantines around the world 
also highlight the ever-growing potential of digital biosociality through platforms.

\section{Digital Biopower}

Foucault (1990: 139-140) first coined the term biopower in The History of Sexuality to refer to the emergence of various disciplines or institutions (e.g., universities, secondary schools, barracks), hence the "explosion of numerous diverse techniques for achieving the subjugation of bodies and the control of populations". In general, biopower, a new modality of power, reflects the nation state's concerns with prolonging the life of populations and taking control of bodies through regulatory controls (control of populations) and disciplinary techniques (control of the individual body) to gain a normal, healthy body. Technological advancements of the networked society further stimulate surveillance techniques to control populations, thus the excess of biopower in a panoptic gaze (Foucault 2003). In the Foucauldian notion of power, biopower is not considered a repressive form of power but one that acts on and through individuals' actions, desires, motives, bodies, and produces relationships by giving them a sense of freedom and control (Foucault 1980). Thus, biopower incorporates the seamless coalescence of disciplinary techniques for optimizing and managing bodies (Hiley 1984). Indeed, modern medicine as a disciplinary entity has long had the utmost influence on shaping our bodies as a means to maximize health, prevent death, and regiment our subjectivities. Nation state and health institutions were the sole legitimate locus of control over the patient body and health and sharing of private health data, and they employed 'security' and 'fear' as discourses of power in this process (Epstein 2006) in order to sensitize people for privacy.

With advancements in new technologies, new forms of biopower emerge. For example, when the Covid pandemic emerged, in order to limit the spread of the virus, governments benefited from digital technologies to engage in contact tracing and track individuals from phone data. Trace-together application in Singapore enabled health authorities to contact those who might have been exposed to the virus (https://www.tracetogether.gov.sg). For those who do not use such mobile apps, trace together token is distributed to citizens, which is a physical device that exchanges Bluetooth signals with other tokens and mobile apps nearby in order to enable digital contact tracing. Interestingly, the government promotes it as voluntary and community driven contact tracing and responsibilizing citizens to act to protect themselves, their loved ones and their communities who may be at risk and provide guidance to circumvent the effects of the virus. QR code technology is also used in Russia and China to track citizens and enforce quarantining. Despite all these questionable uses of digital 
technologies by nation states (Kitchin 2020), many governments have exposed their vulnerability and insufficiency when fighting with the virus. As the influence of biopower to control the spread of Covid weakens, governments turn not only to their citizens, but also communities and market/alternative market institutions to collectively fight with the virus and manage patient care.

\section{Towards Digital Biosociality and the Rise of Biosocial Surveillance}

In biopower, the patient body was treated as a medium through which the state and healthcare providers perform their regulatory and overly deterministic actions to provide unidirectional care to the patient. Moving beyond the controlling and dominating aspirations of biopower, the healthcare market now encounters the rising participatory and productive capabilities of patient-citizens and healthcare actors on platforms, and the new sociocultural, sociomaterial, and communal production of medicine and control of diseases in the healthcare system. As new technologies and digital platforms exhibit potentials to change the dynamics of government control and dominant expertise system in healthcare, patients - once dominated and dormant - are beginning to be increasingly involved in their own and others' care in collaboration with governmental agencies and platform businesses for vaccine discovery. A new kind of shared and user-driven medicine is on the rise with the increased creative efforts and active engagement of patients in the medical knowledge generation process.

In healthcare platforms such as PatientsLikeMe, 23andMe, and Raremark, patients contribute to the generation of collective medical knowledge and clinical research together with other patients, pharmaceuticals, physicians/researchers, and government. These platforms create a community of diverse healthcare actors and challenge the conventional ways of practicing medicine and conducting medical research by conventional medical experts. The conventional ways treat physicians and their patients as well as other healthcare market actors such as governments, pharmaceuticals and research institutions as alienated and distinct entities. For example, PatientsLikeMe (PLM) - as a Medicine 2.0 platform organization (re)connects market actors to each other for medical research and knowledge generation, reinforces collaboration among these actors by combining patient generated data and expert medicine in the design of medical research and generation of medical knowledge, and enabling proactive relations with healthcare actors in and beyond its platform. 23andMe platform advances genetics research with direct and increased patient inclusion in this democratized and accessible research process as well as sharing of self-reported genetics data by 
patients with other healthcare actors on the platform. Raremark is an online platform of patients with rare diseases, and it serves to raise knowledge and awareness about such diseases through building a research network of rare disease patients and their families, and inform pharmaceutical companies about patient generated data to deliver fast and smarter innovative solutions and enable them to have access to a large rare disease patient pool to recruit them for clinical trials. During the Covid pandemic patients and healthcare providers have collaborated for developing and refining the Covid symptoms tracker on PLM, and then used this surveillance tool for reporting symptoms and comparing treatments received. Platforms enable these initiatives and speed up the pandemic tracking process inclusive of individual patients for the discovery of vaccines. Patient-citizen generated data on health platforms through these surveillance tools are a real-time response to fast-evolving global sanitary crises and early detection (Joshi et al. 2020) and monitoring the spreading (Knight 2020) of the virus.

In order to articulate the roles and relations among healthcare actors for tracking and controlling the effects of Covid, I refer to Rabinow's (1996: 102) concept of "biosociality", which puts emphasis on the new ways of engagement of individuals in sharing experiences and changing their relations to their social and professional environments, and their lifestyles. Biosociality allows for rethinking the emergence and development of new socialities as our knowledge and understanding of diseases and medical data transform via new inclusive ways of management of patient datafication and care. Biosocial collectivities - gathered around a shared somatic experience - bring about new configurations of roles and relations among healthcare actors (Rabinow 1996; Rose 2007), a new kind of solidarity against the pandemic and for medical research and knowledge generation. Patient care and corporeal experiences are now (re)designed by new forms of intervention with other patients, medical experts, government agencies, researchers and the like; thereby initiating new forms of biosociality for disease control and prevention. Patient body is no longer an object of one-way surveillance and domination by the superior medical gaze and government control. Platforms enable patients to not only exert control over their and others care and bodies but also actively participate in clinical research, a domain in which the dominant experts were clinicians and academics, who conducted and validated their research with total control over the scientific research process.

What we observe now is that patients and other healthcare actors engage jointly in biosocial surveillance enabled by platforms. This entails a systematic, social, and real-time process that involves constant monitoring, collection, analysis, aggregation, and dissemination of shared private health data and the resulting discovery 
of medical knowledge and management of patient care through communities of patients, doctors, researchers, pharmaceuticals government agencies and the like. The rise of biosocial surveillance through digital biosocialities (Rabinow 1996) shifts the responsibility of state institutions for surveilling populations to new healthcare platforms and patient communities, and surveillance becomes concurrently as much a caring practice as a disciplinary tool (Lyon 2006). When governments and healthcare institutions fall short on controlling the spread of the virus and ensuring patient health, alternative market solutions and open source initiatives emerge to engage in biosocial surveillance and support healthcare institutions. For example, the open source project CoEpi (Community Epidemiology in Action) "is a privacy-first system for anonymous Bluetooth proximity-based exposure alerting based on voluntary symptom sharing" (https://www.coepi.org). Acknowledging the gap between the government and individual actions such as hygiene control and physical distancing, these open source platform initiatives aim to close this gap using smart phone technologies and cloud computing, and enable people to anonymously track their own contacts, and keep themselves and their immediate environments in the know concerning elevated virus risks and symptoms and compare their symptoms with others infected with the virus.

Moreover, wearable technologies such as Immutouch (https://immutouch.com) also take part in this biosocial surveillance in order to prevent the spread of the virus and enable users to surveil and control their bodily movements not only for self-care but also for the care of communities. This smartband technology vibrates and warns users whenever they attempt to touch their faces, hence prevents the spread of germs and viruses. Such self-tracking practices via wearable technologies are manifestations of body biopolitics that responsibilize patient citizens to be in charge of their bodies through the neoliberal ethos of self-care and empowerment (Lupton 2014), and participatory surveillance (Albrechtslund, 2008) rather than coercive surveillance techniques (Ajana 2017) by the state and the market.

Another example of a biosocial community that emerged during the Covid crisis in order to make up for the insufficiencies of governments and health institutions for managing emergency patient care is Coronavirusmakers ${ }^{1}$. This open source Do-it-Yourself (DIY) maker community from Spain has designed masks and mechanical ventilators for patients with mild symptoms through 3-D printing

\footnotetext{
${ }^{1}$ https://www.forbes.com/sites/ashoka/2020/03/23/respirators-from-3d-printers-how-thespanish-maker-community-fights-covid-19-from-their-living-rooms/amp/
} 
technology to provide fast solutions to health institutions that were in urgent need of medical equipment to provide vital care for patients admitted to hospital emergency rooms and the market lacked the manufacturing capacity for such lifesaving equipment in a short time. Many citizens (including doctors from different countries, engineers, students, teachers, business people) got together on this platform to brainstorm and experiment designs and ideas, build prototypes and use 3D printing to produce the equipment and respond to the worldwide medical shortage.

\section{Concluding Remarks on the Limits of Biosocial Surveillance}

Platformization of Covid further responsibilizes the patient citizen in generating data and tracking the virus, hence giving a sense of control to the patient over medical data generation and patient care through digital biosocial communities. Platforms as dominant organizational forms, however, extract value and make profit on vast amounts of patient data under emerging forms of surveillance capitalism (Zuboff 2019). Critical scholars draw attention to the dangers of pervasive surveillance capitalism, and crises like Covid perpetuate sociotechnical vulnerability due to the rising infodemic (i.e., spread of misinformation) aggravated through digital platforms (Donovan 2020) and intensify racial inequalities (French and Monahan 2020). Patients are desperately seeking for solutions to combat the virus on social media platforms, and they fall prey to any solution, reliable or not. Such manipulation of vulnerability calls for systematic control of infodemic through sorting, ranking and prioritizing critical and reliable data (Donovan 2020). Kitchin (2020) also lists critical issues related to the efficiency and effectiveness of digital technologies to control the spread of Covid, which relate to civil liberties, technical and data quality and manipulation issues, and further propagation of the underpinnings and practices of surveillance capitalism. The dominant reductionist discourse of privacy as an individual right versus solidarity for public good in surveillance capitalism aims to legitimize the commercialization and exploitation of health data for profit via platform organizations (Ajana 2017). Nevertheless, privacy advocates further perpetuate the binary thinking of what is sold for profit by privately held platforms versus what could be used for public good. That is, vexing issues persist about not only putting one's private health data in the hands of platforms which then sell it to pharmaceuticals and research institutions that may have a vested interest exclusive of the interest of the society at large. There also continue to persist security issues related to data hacking and scraping, and data discrimination. 
While such concerns are legitimate, they are contingent and contextual. We are in the midst of a world health and sanitary crisis, and in such contingencies, sharing of data and data philanthropy (Tatevossian 2011) by platforms become ever more important if used for the purposes of science and public health and under full protection of civil rights. Decentralization of biosocial surveillance makes health data sharing a shared responsibility and liability including all the stakeholders involved. What is required of us is to clearly identify these responsibilities for not only data for good but also privacy for good, ensuring data security and preventing manipulation of data by macro institutions, and managing patient literacy as they increasingly become bio digital citizens (Petersen 2018) for sharing, surveilling, and generating medical knowledge, hence influencing science.

Furthermore, reinstalling people's trust in governmental agencies for protecting citizen rights and civil liberties and eradicating the belief that these rights and liberties are not traded for public health will be vital, and complete transparency and precision is required regarding the use, aim, and sharing of patient data (Kitchin 2020). To ensure that the use of technologies for collecting patient data is deployed safely and responsibly for public good, UN Global Pulse, an initiative by United Nations Secretary General, established a network platform of companies, academics and research institutions, UN agencies and member states in order to apply advanced analytics and artificial intelligence to manage infodemic, develop predictive systems to model the spread of the virus and how it influences public health decisions, identify the overall impact of the epidemic on areas such as food security, education and access to healthcare, and deploy the best data governance practices. Such initiatives will be important for the legitimation and reinforcement of biosocial surveillance in the best interest of patient citizens and public health. 


\section{References}

Ajana, Btihaj (2017), "Digital Health and the Biopolitics of the Quantified Self," Digital Health, 3, 1-18. https://doi.org/10.1177/2055207616689509

Albrechtslund, Anders (2008), "Online Social Networking as Participatory Surveillance," First Monday 13 (3) (accessed on December 15, 2020.2 [available at: https://firstmonday.org/article/view/2142/1949]

Beer, David (2009), "Power through the algorithm? Participatory Web Cultures and the Technological Unconscious," New Media \& Society, 11 985-1002. https://doi.org/10.1177/14614448809336551

Donovan, Joan (2020), "Here's how Social Media can Combat the Coronavirus 'Infodemic'," MIT Technology Review, (accessed on June 15, 2020), [available at: https://www.technologyreview.com/2020/03/17/905279/facebook -twitter-social-media-infodemic-misinformation]

Epstein, Charlotte (2006), Guilty Bodies, Productive Bodies, Destructive Bodies: Crossing the Biometric Borders, International Studies Association Conference.

Foucault, Michel (1980), "Truth and Power", in Gordon, Colin (ed.), Power/Knowledge: Selected Interviews and Other Writings 1972-1977 by Michel Foucault, 109-33.

(1990), The History of Sexuality. New York: Vintage Books.

(2003), Society Must be Defended: Lectures at the College de France, 1975-1976. New York: Picador.

French, Martin, and Torin Monahan (2020), "Dis-ease Surveillance: How might Surveillance Studies Address COVID-19?" Surveillance \& Society, 18 (1), 1-11. https://doi.org/10.24908/ss.v18i1.13985

Gibbon, Sahra and Carlos Novas (2008), "Introduction," in Biosocialities, Genetics and the Social Sciences -Making Biologies and Identities. London: Routledge.

Gillespie, Tarleton (2010), The Politics of "Platforms," New Media \& Society, 12, 347-64. https://doi.org/10.1177/1461444809342738

Haggerty, Kevin D. and Richard V. Ericson (2000), "The Surveillant Assemblage," British Journal of Sociology, 51 (4), 605-22. https://doi.org/10.1080/00071310020015280

Helmond, Anne (2015), "The Platformization of the Web: Making Web Data Platform Ready," Social Media and Society, 1 (2), https://doi.org/10.1177/2056305115603080

Hiley, David R. (1984), "Foucault and the Analysis of Power: Political Engagement without Liberal Hope or Comfort," Praxis International, 4 (2), 192-207. 
Joshi, Aditya, Ross Sparks, James McHugh, Sarvnaz Karimi, Cecile Paris and Raina MacIntyre (2020), "Harnessing Tweets for the Early Detection of an Acute Disease Event," Epidemiology, 31 (1), 90-97, https://doi.org/10.1097/EDE.0000000000001133

Kitchin, Rob (2020), "Civil Liberties or Public Health, or Civil Liberties and Public Health? Using Surveillance Technologies to Tackle the Spread of COVID-19," Space and Polity, 362-81 https://doi.org/10.1080/13562576.2020.1770587

Knight, Will (2020), "How Al is Tracking the Coronavirus Outbreak," Wired, (accessed on February 8, 2020), [available at: https://www.wired.com/story/how-ai-tracking-coronavirusoutbreak/]

Lyon, David (2006), "The Search for Surveillance Theories," in D. Lyon (Ed.), Theorising Surveillance: The Panopticon and Beyond, 3-20, Portland: Willan Publishing.

Lupton, Deborah (2014), "Quantified Sex: A Critical Analysis of Sexual and Reproductive Self-tracking Using Apps," Cult Health Sex, 17, 1-14. https://doi.org/10.1080/13691058.2014.920528

Ozgun, Aras (2018), "[Cntrl] + [Alt] + [Esc] ? Virtual Platforms as Spaces of Control and Contestation," Markets, Globalization \& Development Review, 3 (3), https://doi.org/10.23860/MGDR2018-03-03-01

Petersen, Alan (2018), Digital Health and Technological Promise: A Sociological Inquiry. Abingdon, Oxon: Routledge.

Rabinow, Paul (1996), Artificiality and Enlightenment: From Sociobiology to Biosociality: Essays on the Anthropology of Reason. Princeton University Press: NJ.

Rose, Nikolas (2007), The Politics of Life Itself: Biomedicine, Power, and Subjectivity in the Twenty-First Century. Princeton University Press: NJ.

Tatevossian, Anoush Rima (2011), "Data Philanthropy: Public \& Private Sector Data Sharing for Global Resilience," UN Global Pulse, (accessed on December 16, 2020), [available at: https://www.unglobalpulse.org/2011/09/data-philanthropy-publicprivate-sector-data-sharing-for-global-resilience/]

Van Dijck, José (2013), The Culture of Connectivity: A Critical History of Social Media. Oxford and New York: Oxford University Press.

Zuboff, Shoshana (2019), The Age of Surveillance Capitalism: The Fight for a Human Future at the New Frontier of Power. NY: PublicAffairs. 